Berkala Ilmu Perpustakaan dan Informasi, Vol. 16, No. 2, Desember 2020, Hal. 224-238 DOI: 10.22146/bip.v16i1.645

ISSN 1693-7740 (Print), ISSN 2477-0361 (Online)

Tersedia online di https://journal.ugm.ac.id/v3/BIP

\title{
WebGIS sebagai media diseminasi kemas ulang informasi
}

\author{
Nurida Maulidia Rahma ${ }^{1,2}$ \\ ${ }^{1}$ Pascasarjana, Program studi Inovasi Regional, Universitas Padjadjaran \\ ${ }^{2}$ Pusat Data dan Dokumentasi Ilmiah, Lembaga Ilmu Pengetahuan Indonesia \\ ${ }^{1} J a l a n$ Dipati Ukur, Dago, Kecamatan Coblong, Bandung, 40132 \\ ${ }^{2}$ Jl. Jendral Gatot Subroto No. 10, Jakarta Selatan 12930 \\ e-mail:nurida19002@mail.unpad.ac.id
}

Naskah diterima: 31 Agustus 2020, direvisi: 5 Oktober 2020, disetujui: 23 Oktober 2020

\begin{abstract}
ABSTRAK
Pendahuluan. Tidak semua karya ilmiah maupun produk hasil kegiatan ilmiah lainnya dapat dengan mudah dimanfaatkan langsung oleh masyarakat. PDDI sendiri belum maksimal dalam memanfaatkan dan menyebarkan produk pengetahuan. Produk pengetahuan seharusnya dirangkai, divisualisasikan dan diinformasikan melalui media digital. Tulisan ini bertujuan untuk mengetahui apakah WebGIS dapat digunakan sebagai media penyebaran kemas ulang informasi yang berupa pohon industri interaktif.

Metode penelitian. Metode yang digunakan adalah kualitatif metode deskriptif.

Data analisis. Analisis secara deskriptif. Hasil analisis survei dikaji dengan hasil studi literatur sehingga dapat ditarik kesimpulan untuk menjawab pertanyaan penelitian.

Hasil dan Pembahasan.Survei menunjukkan bahwa masyarakat Banyuwangi menghendaki pohon industri interaktif dipasangkan (menjadi konten) di WebGIS (BAGEOS) milik Pemerintah Kabupaten Banyuwangi. Dari survei menunjukkan bahwa selain bermanfaat bagi BAGEOS, pemasangan pohon industri pada BAGEOS juga akan dirasakan masyarakat karena informasi lebih cepat sampai ke masyarakat.

Kesimpulan dan Saran. Kombinasi/kolaborasi antara pohon industri dengan WebGIS atau peta digital merupakan kombinasi yang baik. Hal ini dapat dilihat dari respon responden bahwa semua responden menyetujui pemasangan pohon industri di peta digital. GIS mampu menjadi media penyebaran kemas ulang informasi. Selanjutnya, penulis menyarankan agar persepsi masyarakat Banyuwangi tersebut ditindaklanjuti dengan kegiatan evaluasi pemanfaatan sehingga akan didapat perbaikan.
\end{abstract}

Kata kunci: media kemas ulang informasi; kemas ulang informasi; gis; webgis; pohon industri interaktif

\section{ABSTRACT}

Introduction. Not all scientific work can be easily utilized directly by the public (society). Pusat Data dan Dokumentasi Informasi Ilmiah (PDDI) has not optimally disseminated knowledge products. The knowledge products should be assembled, visualized and informed - through digital media. This paper aims to examine whether WebGIS can be used as a medium for disseminating information.

Data Collection Method. The method used was descriptive qualitative. Data collection was conducted by means of a survey.

Data Analysis. This research use descriptive analysis. The results of the survey analysis were reviewed with the results of literature studies so that conclusions could be drawn to answer the research questions.

Results and Discussions. The survey shows that the Banyuwangi community expect that an interactive industrial tree to be attached in the WebGIS (BAGEOS) of the Banyuwangi Regency Government. The survey shows that installing industrial trees on BAGEOS is not only beneficial for BAGEOS, but also for the community. 
Conclusions. Combination between industrial trees with WebGIS or digital maps is a good combination. All respondents agreed to pair industrial trees on digital maps. GIS is capable as a medium for disseminating information packaging.

Keywords: media repackaging information; repackage information; gis; webgis; interactive industrial tree

\section{A. PENDAHULUAN}

Pusat Data dan Dokumentasi Informasi Ilmiah (PDDI) adalah salah satu satuan kerja (satker) Lembaga Ilmu Pengetahuan Indonesia (LIPI) yang memberikan layanan ilmu pengetahuan, teknologi, dan informasi. Sebagai layanan informasi, PDDI berperan serta dalam mendiseminasikan hasil penelitian. Salah satu layanan yang diberikan PDDI kepada masyarakat terkait dengan penelitian yaitu dengan membuatkan suatu produk pengetahuan. Terdapat beberapa produk yang dihasilkan PDDI untuk mendiseminasikan informasi, salah satunya adalah pohon industri. Produk tersebut merupakan hasil dari pengolahan karya ilmiah yang dikemas ulang agar dapat dipahami dan dimanfaatkan oleh masyarakat luas.

Pohon industri dimaksudkan untuk membantu masyarakat untuk melakukan diversifikasi produk olahan dari komoditas yang ada di lingkungan sekitarnya. Selain dapat dimanfaatkan oleh masyarakat, produk pengetahuan ini dapat dimanfaatkan juga oleh pemerintah dalam pengambilan kebijakan terutama dalam hal pengembangan sumber daya manusiany. Untuk para akademisi, pohon industri juga dapat dimanfaatkan sebagai bahan untuk meakukan kajian lebih lanjut.

Seperti yang tercantum pada gambar 1 , di bagian paling kanan gambar terdapat beragam produk hasil olahan misalnya Manisan, Asinan, Acar Nanas dalam botol, Acar Nanas dalam kaleng, Obat Antihemolitik, Nata de pina, Anggur, dsb. Produk hasil olahan tersebut merupakan hasil olahan dari beberapa bagian buah nanas, misal bagian daun, tangkai dan bonggol, kulit, dan daging buah. Rangkaian informasi hasil olahan tersebut dihasilkan dari analisis artikel dan/atau karya ilmiah yang dilakukan oleh pustakawan/tim pohon industri PDDI.
Seperti yang diketahui bersama, bahwa tidak semua karya ilmiah maupun produk hasil kegiatan ilmiah lainnya dapat dengan mudah dimanfaatkan langsung oleh masyarakat. Hal ini dikarenakan ketidaktahuan masyarakat dalam mengakses dan memilah informasi yang begitu cepat pertumbuhannya. Selain permasalahan ledakan informasi, di PDDI sendiri belum maksimal dalam memanfaatkan dan menyebarkan produk pengetahuan. Selanjutnya, agar produk pengetahuan yang telah dibuat dapat dimanfaatkan oleh banyak masyarakat, maka pembuatan produk pengetahuan berikutnya, yaitu pohon industri yang dibuat pada tahun 2019, -dirangkai, divisualisasikan dan diinformasikan- melalui media peta digital. Peta digital yang digunakan adalah peta digital (WebGIS) yang sudah dibangun oleh pemerintah daerah.

Untuk mengetahui keterbaruan dan kemutakhiran kajian, maka dibutuhkan perbandingan penelitian terdahulu. Hal ini dilakukan untuk menghindari adanya kesamaan kajian. Adapun hasil penelitian terdahulu sebagai berikut:

1. Enemute Basil Iwhiwhu (2008)

Penelitian Enemute Basil Iwhiwhu (2008), berjudul "Information Repackaging and Library Services: A Challenge to Information Professionals in Nigeria". Metode yang digunakan adalah survei. Penelitian ini memiliki tujuan mengkaji pengemasan ulang informasi di perpustakaan. Studi ini juga untuk bermaksud memperkenalkan profesional informasi untuk mengeksplorasi cara-cara baru dalam memberikan layanan. Hasil penelitian pengemasan ulang informasi merupakan salah satu cara untuk meningkatkan layanan perpustakaan, khususnya di era elektronik ini informasi. Pustakawan harus memberikan pemikiran kritis terhadap fenomena ini dengan maksud untuk diimplementasikan layanan 
perpustakaan rutin kepada pengguna. Upaya tersebut cukup besar, tetapi manfaat jangka panjangnya lebih besar daripada kerugian karena tidak menyediakannya.

2. Hasil Penelitian: Tupan dan Wahid Nashihuddin (2015)

Penelitian Tupan dan Nashihuddin (2015), berjudul "Kemas Ulang Informasi untuk Pemenuhan Kebutuhan Informasi Usaha Kecil Menengah: Tinjauan Analisis di PDII-LIPI". Metode yang digunakan adalah deskriptif kualitatif. Penelitian ini memiliki tujuan untuk mendiskripsikan: 1) jenis-jenis produk kemasan informasi; 2) proses kemas ulang informasi; dan 3) upaya pemenuhan kebutuhan informasi usaha kecil menengah (UKM) melalui kemasan informasi PDII-LIPI. Hasil penelitian yaitu diketahuinya: 1) jenis-jenis produk hasil kemas ulang informasi yang dimiliki oleh PDII-LIPI, antara lain: fokus informasi Indonesia,paket informasi teknologi, informasi kilat, tinjauan literatur, panduan usaha, pohon industri, dan film animasi; 2) adapun proses pembuatan paket kemas ulang informasi PDII-LIPI, yaitu penetapan topik, penelusuran literatur, analisis literatur, menyusun desain/template, penggandaan paket informasi, dan pembuatan laporan; serta 3) upaya lembaga untuk memenuhi kebutuhan informasi UKM adalah melalui produk kemas ulang informasi, yaitu: promosi, identifikasi kebutuhan, memilih sumber-sumber informasi, penawaran produk, evaluasi pemanfaatan produk, dan membuat kebijakan inovatif.

3. Hasil Penelitian: Ira Maryati dan Ambar Yoganingrum (2015)

Penelitian Maryati dan Yoganingrum (2015), berjudul "Information Packaging Process for Solving the Lack of Information Literacy in Coastal and Small Island Areas in Indonesia". Metode yang digunakan adalah deskriptif kualitatif. Penelitian ini memiliki tujuan untuk mengetahui bentuk kemas ulang informasi yang sesuai dengan masyarakat di daerah kepulauan dan terpencil. Hasil kajian menunjukkan bahwa bentuk kemas ulang informasi yang sesuai dengan masyarakat di daerah kepulauan dan terpencil adalah animasi video.

\section{Muchlis (2017)}

Penelitian, berjudul "Analisis Kemas Ulang Informasi di Perpustakaan Utsman Bin Affan Universitas Muslim Indonesia". Metode yang digunakan adalah deskriptif kualitatif. Penelitian ini memiliki tujuan untuk mengetahui proses kemas ulang informasi yang telah dilakukan oleh pihak perpustakaan Utsman Bin Affan Universitas Muslim Indonesia, dan mengetahui bagaimana bentuk kemas ulang informasi yang telah disediakan oleh pihak perpustakaan Utsman Bin Affan Universitas Muslim Indonesia. Hasil penelitian yaitu Proses kemas ulang informasi di perpustakaan Utsman Bin Affan Universitas Muslim Indonesia belum terealisasi dengan baik sebab pihak perpustakaan hanya menyediakan bentuk kemas ulang seperti katalog buku, bibliografi, brosur, leaflet, spanduk, serta kumpulan kegiatan yang diambil dalam bentuk foto atau gambar kemudian dirangkum ke dalam aplikasi yang akan menghasilkan video dokumenter. Pihak perpustakaan belum menyediakan bentuk kemas ulang informasi yang memang relevan dengan kebutuhan pemustaka seperti halnya partfinders, majalah abstrak, maupun majalah indeks.

\section{Listianawati (2018)}

Penelitian Listianawati (2018), berjudul "Kemas Ulang Informasi sebagai Layanan Unggulan di Perpustakaan IPC Corporate University Bogor". Metode yang digunakan adalah kualitatif. Penelitian ini memiliki tujuan untuk mengetahui jenis-jenis kemas ulang informasi, proses pengemasan informasi, dan pemasaran kemas ulang informasi yang ada di Perpustakaan IPC Corporate University Bogor. Hasil penelitian menunjukkan bahwa Perpustakaan IPC Corporate University Bogor memiliki berbagai jenis kemas ulang informasi, antara lain pembuatan abstrak, quotes menarik dari buku, tips menarik dari buku, CAS, SDI, dan infografis tentang kepelabuhanan. Adapun tahapan yang dilakukan dalam proses pengolahan kemas ulang informasi tersebut 
antara lain: 1) mengidentifikasi topik terbaru, 2) mengumpulkan sumber informasi melalui riset kecil, 3) melakukan repackaging, 4) menyebarluaskan, dan 5) melakukan evaluasi. Selain itu hasil penelitian menunjukkan bahwa terdapat beberapa tahapan terkait dengan pelaksanaan pemasaran kemas ulang informasi di Perpustakaan IPC Corporate University Bogor. Tahapan tersebut antara lain: perencanaan, pelaksanaan pemasaran, dan pengukuran hasil pemasaran selama periode tertentu.

\section{Aya Yahya Maulana dan Danang Dwijo Kangko (2018)}

Penelitian Maulana dan Kangko (2018), berjudul "Kemas Ulang Informasi sebagai Solusi Alternatif Literasi Hukum Wakaf Uang: Sebuah Studi Literatur". Metode yang digunakan adalah deskriptif. Penelitian ini memiliki tujuan untuk memberikan gambaran pelaksanaan wakaf uang di Indonesia, mengidentifikasi permasalahan yang terjadi, serta memberikan alternatif solusi praktis permasalahan tersebut dari sudut pandang kepustakawanan. Hasil penelitian menunjukkan bahwa permasalahan yang dihadapi dari sisi masyarakat ialah kurang tepatnya persepsi mengenai hukum wakaf uang. Selain itu, masih rendahnya pengetahuan atau keterampilan (literasi) dalam bidang atau aktivitas wakaf uangturut menjadi masalah. Sedangkan dari sisi regulator dan operator, sosialisasi telah coba dilakukan akan tetapi hal tersebut belum maksimal. Adapun alternatif solusi yang dicanangkan untuk permasalahan tersebut adalah dengan melakukan kemas ulang informasi. Beberapa penelitian tentang kemas ulang informasi menunjukkan bahwa upaya tersebut dapat digunakan untuk menyampaikan informasi dengan baik. Hal ini dapat menjadi solusi agar penyampaian informasi hukum wakaf uang lebih mudah diterima oleh masyarakat. Selain itu, kemas ulang informasi juga digunakan sebagai sarana untuk meningkatkan literasi hukum wakaf uang di masyarakat. Sebenarnya masih ada banyak alternatif pilihan jenis produk kemas ulang yang dapat dipilih oleh regulator dan operator wakaf.
Dan setiap jenis produk kemas ulang tersebut memiliki kelebihan masing-masing. Maka disarankan agar dilakukan penelitian mengenai pemilihan jenis produk kemas ulang dan prosesnya lebih lanjut karena hal tersebut belum termasuk dalam cakupan penelitian ini.

Berdasarkan uratan tersebut di atas, terlihat bahwa penelitian yang banyak dilakukan adalah penelitian kemas ulang informasi terkait dengan jenis dan proses pembuatannya. Selain itu, kajian terdahulu menunjukkan bahwa belum pernah dilakukan kajian diseminasi kemas ulang informasi (pohon industri interaktif) menggunakan peta digital atau WebGIS. Dalam tulisan ini memiliki bahasan terkait dengan media diseminasi pohon industri interaktif dimana media yang digunakan ialah peta digital (WebGIS). Tulisan ini bertujuan untuk mengetahui pendapat dari stakeholder mengenai WebGIS yang digunakan sebagai media penyebaran kemas ulang informasi (pohon industri interaktif). Dengan kata lain pertanyaan penelitiannya adalah apakah WebGIS dapat digunakan sebagai media penyebaran kemas ulang informasi yang berupa pohon industri interaktif.

\section{B. TINJAUAN PUSTAKA Kemas Ulang Informasi}

Kemas Ulang Informasi merupakan proses dari kegiatan menganalisis kumpulan informasi, atau mengubah format (bentuk/media) suatu informasi ke format lainnya sesuai dengan kebutuhan pemakai (Djamarin, 2016; Dongardive, 2013).Agada (1995) menyebutkan bahwa layanan kemas ulang informasi merupakan upaya mengatasi ledakan informasi dan persaingan untuk dukungan informasi yang cepat, andal, mudah dan efisien untuk pengambilan keputusan.Tupan dan Nashihuddin (2015) berpendapat bahwa kemas ulang informasi bertujuan untuk beberapa hal diantaranya untuk menyajikan informasi dalam bentuk kemasan yang lebih menarik, menyediakan hasil ringkasan atau analisis informasi, menyediakan sarana dan panduan untuk menyusun kemasan informasi, mengumpulkan informasi mutakhir dari berbagai sumber baik dalam maupun luar 
negeri, dan mengulas atau meninjau berbagai literatur dan dokumen yang telah dikumpulkan yang dapat diterima pengguna secara langsung dan mudah dimengerti isinya. Ada beragam jenis produk kemasan informasi yang disediakan oleh PDII (sebelum berubah nama menjadi PDDI), yaitu: Paket Informasi Teknologi, Informasi Kilat, Pohon Industri, Panduan Usaha, Tinjauan Literatur, Fokus Informasi Indonesia, dan film animasi. Dari beragam jenis produk kemasan informasi tersebut, menurut Maryati dan Yoganingrum, 2015, kemasan informasi dengan dasar gambar bergerak dan suara seperti film animasi 3D memudahkan masyarakat memahami dan menggunakan informasi. Kemasan informasi yang masih dikerjakan PDDI ialah kemasan yang berformatkan visualisasi dari kumpulan informasi. Salah satunya adalah pohon industri interaktif. Dalam format yang tersedia saat ini, menurutGrover, Greer, and Agada (2010), peran profesional informasi telah diperluas dengan memasukkan keahlian di media yang lebih baru untuk menyebarkan informasi, termasuk internet.

Mempublikasikan/menyebarkan hasil kemas ulang informasi merupakan strategi mengemas informasi yang sering terlupakan. Mempublikasikan merupakan kegiatan yang sama dengan kegiatan mendiseminasikan informasi. Dalam proses ini, menurut Dongardive (2013)dapat menggunakan berbagai media misalnya buletin, lembaran berita, layanan berita, dan sumber bahan audio visual, untuk digunakan menyebarkan hasil kemas ulang informasi kepada pengguna. Radhakrishnan and Francis (2018) menyarankan media yang lebih mutakhir yaitu situs web perpustakaan atau blog perpustakaan agar dapat digunakan untuk penyebaran informasi yang dikemas ulang secara efektif.

\section{WebGIS}

GIS dapat didefinisikan sebagai sistem untuk menangkap, menyimpan, memanipulasi, menganalisis, dan menampilkan data yang diindeks secara spasial (Maguire, 1991 dalam Saltenberger, Li, Tsou, and Bahramzi, 2015). Saltenberger, Li, Tsou, dan Bahramzi (2015) menjelaskan lebih lanjut bahwa secara tradisional, GIS sangat tersentralisasi dan membutuhkan pengguna yang berpengetahuan. Perangkat lunak ini biasanya disimpan di komputer desktop individu dan dioperasikan oleh spesialis GIS. Integrasi teknologi internet dengan GIS membuat GIS lebih terbuka dan dapat diakses oleh semua orang, sehingga memudahkan ketersediaan dan penyebaran data spasial. Sistem GIS yang disimpan dan dioperasikan melalui internet dikenal sebagai Web GIS (Saltenberger, Li, Tsou, and Bahramzi, 2015). WebGIS adalah proses merancang, mengimplementasikan, menghasilkan dan menyampaikan peta, data geospasial dan fungsi atau layanan sistem informasi geografis di World Wide Web melalui internet (Bendib, Hadda, and Kalla, 2016).

Hampir semua pemerintah daerah di Indonesia memiliki WebGIS. Tidak hanya di Indonesia, pemetaan digital sudah dilakukan secara global. Bahkan terdapat komunitas yang melakukan pemetaan terhadap ruang hijau (peta tersebut disebut dengan "Green Map"). Green map tersebut ditujukan sebagai alat untuk mengatasi global warming. Peta Hijau akan memberikan panduan kepada pembaca peta untuk mengatasi perubahan iklim. Misalnya, Pembuatan Peta di Kuba, Pembuat Peta Hijau membantu membangun hutan bakau di Rincón de Guanabo yang tahan terhadap Badai Irma pada tahun 2017; membantu membuat kebijakan - di Malmo Swedia, Peta Hijau di kota tersebut menampilkan salah satu tempat paling melindungi iklim di dunia dan masih banyak lagi contoh pemanfaatan GIS untuk mengatasi perubahan iklim.

GIS telah banyak digunakan oleh berbagai bidang dan lembaga di dunia. Dalam penelitian Baños, Wandosell, and Parra (2016) disebutkan bahwa perusahaan ritel besar telah mengadopsi Web GIS untuk memberikan informasi kepada pelanggan dan untuk tujuan geomarketing. Hal ini menunjukkan bahwa GIS bermanfaat di bidang pemasaran. Bahkan GIS saat ini digunakan sebagai instrumen untuk mengukur dan menganalisis layanan perpustakaan (Bishop \& Mandel, 2010). Dalam penelitian Pournaghi (2017), teknologi GIS diusulkan sebagai solusi 
untuk membantu manajer perpustakaan dan pustakawan untuk mengidentifikasi tingkat pinjaman untuk rak buku yang tersedia di perpustakaan. GIS dapat diubah menjadi sistem otomatis yang mendasari potensi untuk menemukan item yang dicari berdasarkan tingkat pinjaman, untuk menyorotnya pada beberapa peta dan untuk menyajikan peta untuk manajer perpustakaan dan pustakawan di layar. Sistem ini efektif dalam meningkatkan layanan pengembangan koleksi dan mengelola sumber dan, dengan demikian, meningkatkan efisiensi penggunaan koleksi perpustakaan. Selain di bidang perpustakaan, menurut studi yang dilakukan oleh Chang (2017) di China, GIS digunakan untuk memetakan silsilah Bangsa Hakka.

Visualisasi dalam bentuk peta terbukti mempermudah dalam penyampaian dan penggunaan informasi baik spasial maupun nospasial (Capelleveen, n.d.; Pujayanti, Susilo, dan Puspitaningrum, 2014; Wahid, Maulud, Rahman, Bahri, dan Jaafar, 2018). Contohnya saja visualisasi yang digunakan pemerintah untuk menginformasikan penyebaran virus covid-19. Menurut Afifah dan Saraswati (2012) penelitian penyajian data dengan menggunakan peta lebih informatif. Dalam penelitiannya Mehra et al. (2018) memanfaatkan GIS untuk memvisualisasikan informasi mengenai advokasi bagi LGBTI (Lesbian, Gay, Bisexual, Transgender, \& Intersex) sebagai bahan untuk merumuskan kebijakan luar negeri. Untuk membangun WebGIS, Godfrey and Stoddart (2018) menyarankan agar melakukan kolaborasi antar lembaga dan lintas institusi untuk membangun WebGIS bersama.

\section{METODE PENELITIAN}

Metode yang digunakan adalah kualitatif dengan metode deskriptif. Pengumpulan data dilakukan dengan cara survei. Survei dilakukan di Jakarta dan Banyuwangi. Survei di Jakarta dilakukan pada 24 orang peserta workshop pohon industri interaktif. Sedangkan survei di Banyuwangi dilakukan pada 27 orang peserta undangan dalam acara penyerahan pohon industri interaktif. Peserta workshop di Jakarta terdiri dari tim pembuatan pohon industri interaktif PDDI dan peserta dari luar PDDI. Sedangkan responden dari survei yang dilakukan di Banyuwangi adalah masyarakat Banyuwangi yang diundang untuk mengikuti acara penyerahan dan pemasangan pohon industri interaktif di BAGEOS. Pertanyaan inti kuesioner (dengan responden dari Banyuwangi) yang dimaksudkan untuk menjawab penelitian ini adalah "apakah anda setuju Pohon Industri Interaktif di tampilkan di peta Bageos?" berikut dengan "alasannya". Setelah kuesioner diisi, maka selanjutnya hasil survei dianalisis. Analisis dilakukan secara otomatis oleh google form. Kemudian untuk pembahasan kajian lebih lanjut, hasil analisis survei dikaji dari studi literatur sehingga dapat ditarik kesimpulan untuk menjawab pertanyaan penelitian.

\section{HASIL DAN PEMBAHASAN Hasil}

Terdapat dua macam survei yang dilakukan untuk mengumpulkan data. Survei pertama dilakukan di Jakarta, yaitu pada acara Workshop Pembuatan Pohon Industri. Sedangkan survei kedua dilakukan di Banyuwangi, yaitu pada acara penyerahan dan pemasangan Pohon Industri Interaktif ke WebGIS Bageos. Hasil pemasangan pohon industri interaktif ke WebGIS dapat dilihat dengan mengikuti langkah sebagai berikut:

1. Kunjungi WebGIS pada http://gis.banyuwangikab.go.id/.

2. Pilih menu "Peta", pilih tampilan sesuai selera (google map, esri map, atau open street map).

3. Buka layer "Peta Tematik".

4. Beri tanda centang pada "Potensi Pertanian".

5. Beri tanda centang pada buah-buahan yang diinginkan (buah naga, durian, jeruk, cabai, pisang).

\section{Hasil Survei Pohon Industri Interaktif di Jakarta}

Dalam rangkaian kegiatan pembuatan pohon industri interaktif terdapat kegiatan workshop pembuatan pohon industri interaktif dimana turut mengundang peserta dari luar satuan kerja. Dalam workshop ini juga 
digunakan penulis untuk mengumpulkan pendapat/persepsi dari stakeholder terhadap pohon industri dengan cara melalui survei. Survei dilakukan dengan cara menyebarkan kuesioner kepada peserta workshop. Kuesioner diisi oleh 24 peserta workshop. Peserta workshop terdiri dari tim pembuat pohon industri interaktif dan dari luar PDDI. Profesi terbanyak yang dimiliki peserta adalah pustakawan PNS. Profesi lainnya adalah freelance, staf komunikasi dan staf publikasi dan informasi.

Penulis memberikan pertanyaan terbuka di dalam kuesioner untuk mengungkap Apa sajakah manfaat dari Pohon Industri Interaktif bagi peserta workshop. Alhasil persepsi peserta workshop menunjukkan bahwa manfaat dari pohon industri interaktif antara lain mempermudah pihak eksternal untuk mengetahui produk dari instansi; menyediakan jenis kemas ulang informasi alternatif bagi user; mempermudah penyampaian informasi kepada masyarakat mengenai suatu produk tertentu dan dapat lebih menarik; mengetahui manfaat dari suatu produk komoditas tertentu; sebagai media promosi perpustakaan yang interaktif dan menarik; mempermudah dalam pembuatan materi publikasi dan informasi; promosi dan film; pengemasan informasi menjadi lebih menarik; dan bermanfaat sebagai diseminasi informasi. Kebanyakan dari peserta (dilihat dari pengulangan jawaban) berpendapat bahwa pohon industri bermanfaat sebagai kemas ulang informasi. Pohon industri interatif dinilai sebagai bentuk alternatif dalam kemas ulang informasi yang efektif untuk mengemas informasi agar lebih menarik. Masih terkait dengan manfaat, hasil jawaban kuesioner tertinggi berturut-turut menunjukkan bahwa pohon industri interaktif dapat dimanfaatkan oleh Masyarakat Umum (83,3\%), peneliti $(79,2 \%)$, mahasiswa $(70,8 \%)$, pelajar $(62,5 \%)$ dan wirausahawan $(62,5 \%)$.

Pertanyaan ditutup dengan menanyakan saran peserta untuk perbaikan pohon industri interaktif. Peserta yang tidak memberi saran sebanyak empat orang, sedangkan satu orang diantaranya memberi komentar bahwa pohon industri interaktif sudah baik. Adapun saran yang dituliskan peserta antara lain gambar lebih riil, waktunya harus lebih diperpanjang lagi karena untuk menggunakan aplikasi editing menggunakan adobe animate butuh waktu, informasinya terus diupdate, disediakan fasilitas yang mendukung kegiatan, lebih sering dishare di media sosial agar dapat bermanfaat untuk masyarakat luas, semakin disebarluaskan dan aplikasi dibagikan free, agar membuat video tata cara membuat pohon industri agar kita kapanpun dan dimanapun bisa dipelajari, aplikasi lebih sederhana, semoga kedepannya bisa menjadi media pembelajaran yang interaktif, share hasil pohon industri di medsos lainnya, untuk materi dari isi konten pohon industri sebaiknya masing-masing user dapat menambahkan dengan meng-upload dari fasilitas yang disediakan oleh admin publisher dari pohon industri yang sudah ada, tidak hanya berbentuk video singkat tetapi lebih kepada film dokumenter, selain produk, bisa ditampilkan teknologi dan pemasarannya, aplikasi yang digunakan lebih sederhana, sebaiknya menggunakan aplikasi bebas (open) yang lebih mudah dan sederhana (kalau ada), sebaiknya prasarana saat pelatihan seperti layar infocus lebih baik agar terlihat jelas oleh peserta, sebaiknya diberikan cara membuat narasi yang baik pada pohon industri interaktif yang dibuat, untuk hilirisasi, tahapan pembuatan disarankan untuk dijelaskan, -sedikit artikel banyak gambar, tetapi menarik dan mudah dipahami, data dapat dilengkapi mulai dari budidaya, penanganan hama penyakit, hingga pasca panen, serta pemasarannya, disebarluaskan kepada masyarakat umum. Saran-saran dari peserta di atas menunjukkan bahwa peserta menginginkan pembuatan yang lebih mudah dengan maksud agar lebih mudah dipraktekkan di tempat kerja. Hal tersebut menunjukkan bahwa peserta berkeinginan untuk lebih mudah dalam pembuatan pohon industri sehingga mudah mempraktekkan di tempat kerja masingmasing. Hal ini dapat dilihat dari data survei sejumlah 100\% menunjukkan bahwa semua peserta ingin membuat pohon industri di tempat kerjanya. 


\section{Hasil Survei Pohon Industri Interaktif di Banyuwangi}

Survei terakhir dilakukan di Banyuwangi. Jajak pendapat melalui survei dilakukan juga di Banyuwangi dikarenakan pohon industri interaktif 2019 merupakan produk kerja sama antara PDDI LIPI dengan Pemerintah Daerah Kabupaten Banyuwangi. Survei dilakukan pada saat penyerahan sekaligus pemasangan pohon industri interaktif ke peta digital (BAGEOS) milik pemerintah Kabupaten Banyuwangi. Untuk efisiensi, survei dilakukan dengan cara menyebarkan kuesioner. Terdapat 33 tanggapan yang terkumpul namun hanya 27 tanggapan yang dapat disurvei lebih lanjut.

Usia responden terbanyak $(40,7 \%)$ berada di kisaran 30-40 tahun. Jenis kelamin didominasi oleh laki-laki (74,1). Pekerjaan terbanyak adalah dosen yaitu sebesar $63 \%$. Pekerjaan responden lainnya adalah guru, PNS, swasta, dan staf honorer. Sedangkan pekerjaan responden di sektor wirausaha tidak ada.

Berikut penjelasan atas hasil survei terhadap 27 responden. Bagi 17 dari 27 responden pohon industri interaktif merupakan hal yang baru atau belum pernah tau. Sedangkan 10 responden $(37 \%)$ menyatakan sudah pernah tahu. Dari 27 responden, terdapat 24 responden yang menilai bahwa pohon industri interaktif menarik, sedangkan tiga responden menyatakan kurang menarik dikarenakan rasa kecewa terhadap cara penyampaian materi (di Banyuwangi) dan belum memuat obyek yang beragam. Sedangkan alasan para responden memberikan penilaian menarik antara lain dikarenakan interaktif, mampu memberikan (menunjukkan) potensi suatu wilayah dalam berbagai sektor, mengambil salah satu rujukan penelitian, cukup untuk menambah informasi, memudahkan mencari ilmu dan pengetahuan, ingin tahu lebih lanjut, pohon industri interaktif merupakan hal baru untuk dipelajari, pembaharuan informasi, bisa riset potensi daerah, informatif, mudah dipahami dan simple aplikasinya. Dari alasan-alasan tersebut, alasan sering terulang adalah untuk menambah informasi, dan menarik karena formatnya yang interaktif.
Menampilkan pohon industri interaktif pada peta digital merupakan hal yang baru dan belum pernah ada sebelumnya. Tanggapan responden terhadap pohon industri interaktif yang ditampilkan di peta digital (BAGEOS) adalah $100 \%$ setuju. Atas fenomena tersebut, beberapa responden (19 dari 27) menjelaskan alasannya antara lain karena peta wisata lebih detail; agar konten yang ada di BAGEOS lebih beragam; bagus, agar potensi banyuwangi lebih terekspos; mengetahui lokasi komoditi yang ada; cepat diakses oleh publik; GIS (BAGEOS) semakin lengkap; khusus masyarakat banyuwangi terbantu khasanah ke umum; bermanfaat bagi banyak orang; memperkaya aplikasi BAGEOS; interaktif; ada kemungkinan membantu; adanya kolaborasi informasi semakin luas; agar bisa diakses masyarakat; lebih memudahkan peneliti dalam mengakses data; menambah informasi ke masyarakat; akan membuka wawasan terhadap perkembangan keilmuan; membantu memberikan informasi secara lengkap dan terintegrasi. Dapat dikatakan bahwa peta digital yang dimiliki pemerintah Banyuwangi diyakini masyarakat Banyuwangi akan menjadi lebih beragam kontennya apabila di dalamnya terdapat pohon industri interaktif. Selain bermanfaat bagi BAGEOS, manfaat juga akan dirasakan masyarakat sehingga informasi lebih cepat sampai ke masyarakat.

Terkait dengan manfaat yang didapatkan dari pohon industri, 20 responden meyakini bahwa manfaat dari pohon industri adalah sebagai pengetahuan baru, 17 responden berpendapat sebagai ide penelitian, 14 responden berpendapat bahwa dapat digunakan sebagai ide usaha dan ide pengembangan produk, 12 responden berpendapat sebagai bahan ajar (materi pembelajaran) dan 11 responden menyatakan sebagai Ide pengembangan teknologi dan membuat pohon industri serupa dengan tema lainnya. Selain dari pilihan jawaban yang ada di kuesioner, tidak ada satupun responden yang menuliskan pendapat baru selain yang ada di pilihan jawaban kuesioner.

Masih berkaitan dengan manfaat dari pohon industri, menurut responden, yang akan mendapatkan manfaat dari pohon industri 
adalah peneliti $(85,2 \%)$, mahasiswa $(77,8 \%)$, entrepreneur/pebisnis/wirausaha $\quad(77,8 \%)$, masyarakat umum $(77,8 \%)$, dosen $(70,4 \%)$, pelajar $(55,6 \%)$, guru $(44,4 \%)$, dan PNS (44,4\%). Terdapat satu responden yang menambahkan UKM yang dianggap akan mendapat manfaat.

Selanjutnya, dalam kuesioner ditanyakan Apakah Pohon industri juga dapat dimanfaatkan di tempat kerja Bapak/Ibu? Sebanyak 24 dari 27 responden menilai bahwa pohon industri juga dapat dimanfaatkan di tempat kerja responden. Tiga responden menjawab bahwa pohon industri tidak dapat dimanfaatkan di tempat kerjanya.

Dari pertanyaan Apakah Bapak/Ibu ada keinginan untuk membuat Pohon Industri di tempat kerja Bapak/Ibu? Penulis mendapatkan jawaban bahwa 24 dari 27 responden menyatakan berkeinginan untuk membuat pohon industri di tempat kerjanya. Sedangkan tiga responden sisanya menjawab tidak. Tanggapan ini menunjukkan bahwa pohon industri interaktif dinilai sangat bermanfaat sehingga menarik minat para responden untuk membuat pohon industri serupa di tempat kerjanya.

Terkait dengan perbaikan pohon industri selanjutnya, terdapat dua pertanyaan di dalam kuesioner untuk mendapatkan saran perbaikan pohon industri dari para responden. Yang pertama pertanyaan adalah menanyakan mengenai informasi apa saja yang sebaiknya ditambahkan di pohon industri. Dan pertanyaan kedua sekaligus pertanyaan terakhir adalah pertanyaan mengenai saran dan masukan dari responden untuk perbaikan pohon industri.

Rata-rata kebanyakan responden berpendapat bahwa informasi yang seharusnya ditambahkan pada pohon industri adalah informasi teknologi yang digunakan (dalam membuat produk olahan) $(59,3 \%)$, informasi paten dan inovasi $(59,3 \%)$, Informasi Industri (mis. pasar industrinya) $(55,6 \%)$, penjelasan budidaya $(48,1 \%)$, profil peneliti $(44,4 \%)$, dan narahubung peneliti ahli (44,4\%).

Adapun masukan dan saran dari 19 responden untuk perbaikan Pohon Industri antara lain kedepannya pohon industri jalan terus; dibuat lebih beragam sesuai obyek pengguna; sosialisasi; agar mudah diakses untuk publik kapan saja; agar mudah diakses oleh siswa di sekolah; bermanfaat untuk pengembangan ilmu dan teknologi; buat software aplikasi khusus dan langsung link ke LIPI; sosialisasikan kepada masyarakat umum; pengembangan teknologi terbarukan; industri keilmuan terbarukan; melengkapi dengan pemasaran produk; bisa dikembangkan berbagai sektor; pengembangan lebih interaktif lagi; informasi laboratorium; teknologi tepat guna; harus ditindaklanjuti cara pemasaran; sementara sudah cukup bagus; marketplace (pasar); bagaimana untuk ranah kesehatan; dibuat lebih detail dan lebih inovatif; belum ada tutorial pembuatan produk; memberikan informasi tentang pemetaan wilayah produk; kalau bisa mudah diakses dan informatif; perbanyak sosialisasi; pada masing-masing cabang diberi link pada instansi terkait berkaitan pemasaran; lebih banyak komoditas yang dibuat pohon industri. Dari saran-saran yang disebutkan tersebut beberapa responden memiliki saran yang sama. Hal ini terlihat dari saran yang diulang beberapa kali dengan responden yang berbeda, yaitu mengenai sosialisasi, dan kemudahan akses informasi.

\section{Pembahasan}

Melihat bahwa pemetaan dapat memberikan dampak yang positif, maka dengan ide yang sama, PDDI membuat peta untuk pemetaan potensi suatu daerah yang dilengkapi dengan informasi mengenai hasil penelitian/teknologi/paten/inovasi yang berkaitan dengan potensi yang dimiliki. Potensi yang dipertimbangkan adalah kekayaan alam hayati dan potensi wisatanya. Dengan prtimbangan tersebut PDDI memilih Banyuwangi. Selain itu, PDDI memilih Banyuwangi karena Banyuwangi juga sudah memasang WebGIS sehingga akan mempermudah pemasangan pohon industri ke peta digital. Untuk membangun WebGIS, Godfrey and Stoddart (2018) menyarankan agar melakukan kolaborasi antar lembaga dan lintas institusi untuk membangun WebGIS bersama. PDDI bekerja sama dengan pemerintah 
Kabupaten Banyuwangi untuk membuat pohon industri interaktif dari lima komoditas unggul Banyuwangi. Lima pohon industri interaktif tersebut antara lain buah naga, jeruk, cabai, pisang, dan durian. Survei menunjukkan bahwa masyarakat Banyuwangi menghendaki pohon industri interaktif dipasangkan (menjadi konten) di WebGIS (BAGEOS) Pemerintah Kabupaten Banyuwangi.

Mempublikasikan/menyebarkan hasil kemas ulang informasi merupakan strategi mengemas informasi yang sering terlupakan. Mempublikasikan merupakan kegiatan yang sama dengan kegiatan mendiseminasikan informasi. Dalam proses ini, menurutDongardive (2013), dapat menggunakan berbagai media misalnya buletin, lembaran berita, layanan berita, dan sumber bahan audio visual, untuk digunakan menyebarkan hasil kemas ulang informasi kepada pengguna. Radhakrishnan and Francis (2018) menyarankan media yang lebih mutakhir yaitu situs web perpustakaan atau blog perpustakaan agar dapat digunakan untuk penyebaran informasi yang dikemas ulang secara efektif. Tulisan ini mengusulkan media peta digital untuk digunakan dalam penyebaran pohon industri interaktif.

Peta digital yang digunakan sebagai media penyebaran pohon industri interaktif dimiliki oleh pemerintah Kabupaten Banyuwangi yang bernama Bageos. Bageos ini berfungsi untuk membantu memetakan komoditas unggul yang dimiliki Banyuwangi (lihat pada Gambar 4). BAGEOS membantu menampilkan komoditas jeruk di Banyuwangi secara spasial. Kemudian BAGEOS menampilkan informasi tambahan berupa informasi link pohon industri interaktif yang sudah dibuat PDDI. Apabila link tersebut di-copy-paste-kan ke mesin pencarian maka akan terhubungkan ke pohon industri interaktif seperti pada Gambar 2 .

Peta digital BAGEOS merupakan GIS (Geographic Information Systems) atau dalam bahasa Indonesia disebut dengan SIG (Sistem Informasi Geografis). SIG adalah sistem informasi yang mengelola data dimana data ini juga memiliki informasi spasial sehingga dapat menampilkannya secara geografis (dalam bentuk peta). Dari survei pada masyarakat Banyuwangi, tanggapan responden terhadap pohon industri interaktif yang ditampilkan di peta digital (BAGEOS) adalah $100 \%$ setuju. Hal ini dikarenakan, masyarakat menilai bahwa peta digital yang dimiliki pemerintah Banyuwangi diyakini akan menjadi lebih beragam kontennya apabila di dalamnya terdapat pohon industri interaktif. Selain bermanfaat bagi BAGEOS, manfaat pohon industri juga akan dirasakan masyarakat sehingga informasi lebih cepat sampai ke masyarakat.

\section{E. KESIMPULAN}

Kombinasi/kolaborasi antara pohon industri dengan WebGIS atau peta digital merupakan kombinasi yang baik. Sehingga dapat disimpulkan bahwa GIS dapat digunakan sebagai media diseminasi kemas ulang informasi. Hal ini dapat dilihat dari respon responden bahwa semua responden menyetujui (mendukung) pemasangan pohon industri di peta digital. Selain itu, melihat banyak sekali pemanfaatan GIS baik di bidang yang terkait dengan kepustakawanan maupun nonkepustakawanan turut memperkuat kesimpulan bahwa GIS mampu menjadi media penyebaran kemas ulang informasi. Selanjutnya, penulis menyarankan agar persepsi masyarakat Banyuwangi tersebut ditindaklanjuti dengan kegiatan evaluasi pemanfaatan sehingga akan didapat perbaikan.

\section{DAFTAR PUSTAKA}

Afifah, Y. N., \& Saraswati, E. (2014). Pemanfaatan sistem informasi geografis (sig) untuk kajian kartografis persebaran penyakit hiv di kota Semarang tahun 2012. Jurnal Bumi Indonesia, 3(4), 1-11. Retrieved from http://lib.geo.ugm.ac.id/ ojs/index.php/jbi/article/view/673

Agada, J. (1995). Analysis of information repackaging (ir) processes using the instructional systems design (isd) model. Journal of Instructional Science and Technology, 1(1), 1-9. 
Baños, R., Wandosell, G., \& Parra, M. C. (2016). Web gis to enhance relational capital : the case of general merchandise retailers, 20(3), 578-593. https://doi.org/10.1108/ JKM-06-2015-0218

Bendib, A., Hadda, D., \& Kalla, M. (2016). Application of Webgis in the development of interactive interface for urban management in Batna City. Journal of Engineering and Technology Research, 8(2)(May), 13-20. https://doi.org/10.5897/ JETR2015.0579

Bishop, B. W., \& Mandel, L. H. (2010). Utilizing geographic information systems (gis) in library research. Library Hi Tech, 28(4), 536-547. https://doi.org/10.1108/ 07378831011096213

Capelleveen, E. Van. (2005). Information management boosts command \& control. In Geo-information for Disaster Management (pp. 979-995). Berlin: Springer, Berlin, Heidelberg. https://doi.org/ https://doi.org/10.1007/3-540-27468-5 69

Chang, C. C. (2018). Hakka genealogical migration analysis enhancement using big data on library services. Library Hi Tech, 36(3), 426-442. https://doi.org/10.1108/ LHT-08-2017-0172

Djamarin, M. (2016). Pengemasan informasi. Makalah UPT Perpustakaan. Retrieved from http://repository.unp.ac.id/253/1/ Makalah paket informasi.pdf

Dongardive, P. (2013). Information repackaging in library services. International Journal of Science and Research (IJSR), 2(11), 204-209. Retrieved from http://www.ijsr.net/archive/v2i11/MDIwM TM0MDM=.pdf

Godfrey, B., \& Stoddart, R. (2018). Managing in-library use data: putting a web geographic information systems platform through its paces. Information Technology and Libraries, 37(2), 34-49. https://doi.org/10.6017/ital.v37i2.10208

Grover, R. J., Greer, R. C., \& Agada, J. (2010). Assessing information needs : managing transformative library services. United States of America: Libraries Unlimited.
Maryati, I., \& Yoganingrum, A. (2015, June). Information packaging process for solving the lack of information literacy in coastal and small island areas in Indonesia. Paper presented at the General Conference Congress of Southeast Asian Librarians (CONSAL) XVI, Thailand. Retrieved from http://myrepositori.pnm.gov.my/handle/12 $3456789 / 4233$

Mehra, B., Lemieux, P. A., Burwell, C., Hixson, T., Partee, R. P., Stophel, K., \& Wood, N. E. (2018). Expanding LIS education in the US department of state's diplomacy lab program: GIS and LGBTI advocacy in Africa and latin america. Journal of Education for Library and Information Science, 59(3), 4-16. https://doi.org/ 10.3138/jelis.59.3.2018-0016.02

Pournaghi, R. (2017). GIS as a supporting instrument for making decisions about the library sources collection management. Collection Building, 36(1), 11-19. https://doi.org/10.1108/CB-06-2016-0014

Pujayanti, J. A. D., Susilo, B., \& Puspitaningrum, D. (2014). Sistem informasi geografis untuk analisis persebaran pelayanan kesehatan di Kota Bengkulu. Jurnal Rekursif, 2(2), 99-111. Retrieved from http://download. portalgaruda.org/article.php? article $=2993$ $34 \& \mathrm{val}=7008 \&$ title $=$ sistem informasi geografis untuk analisis persebaran pelayanan kesehatan di Kota Bengkulu

Radhakrishnan, S., \& Francis, A. T. (2018). Information repackaging services and products : a study with special reference to naval physical and oceanographic laboratory (npol). Indian Journal of Information Sources and Services, 8(1), 79-82.

Saltenberger, J., Li, Y., Tsou, M. H., \& Bahramzi, S. (2015). Web GIS as a useful tool for the health and social service sector. International Journal of Healthcare Technology and Management, 15(1), 58-72. https://doi.org/10.1504/ IJHTM.2015.070520 
Tupan, T., \& Nashihuddin, W. (2015). Kemas ulang informasi untuk pemenuhan kebutuhan informasi usaha kecil menengah: tinjauan analisis di pdii-lipi. Baca: Jurnal Dokumentasi Dan Informasi, 36(2), 109-124. https://doi.org/10.14203/ j.baca.v36i2.206
Wahid, M. A. A., Maulud, K. N. A., Rahman, M. A., Bahri, M. A. S., \& Jaafar, O. (2018). Integrated infrastructure management using web-gis application. Proceedings of the Pakistan Academy of Sciences: Part A, 55(3), 35-44. Retrieved from https:// www.scopus.com/inward/record.uri?eid=2 -s2.0 - $85071743882 \&$ partner ID $=$ 40\&md5=73f4b798647c8dc0333b007d66 $7 \mathrm{~d} 0108$ 


\section{DAFTAR GAMBAR}

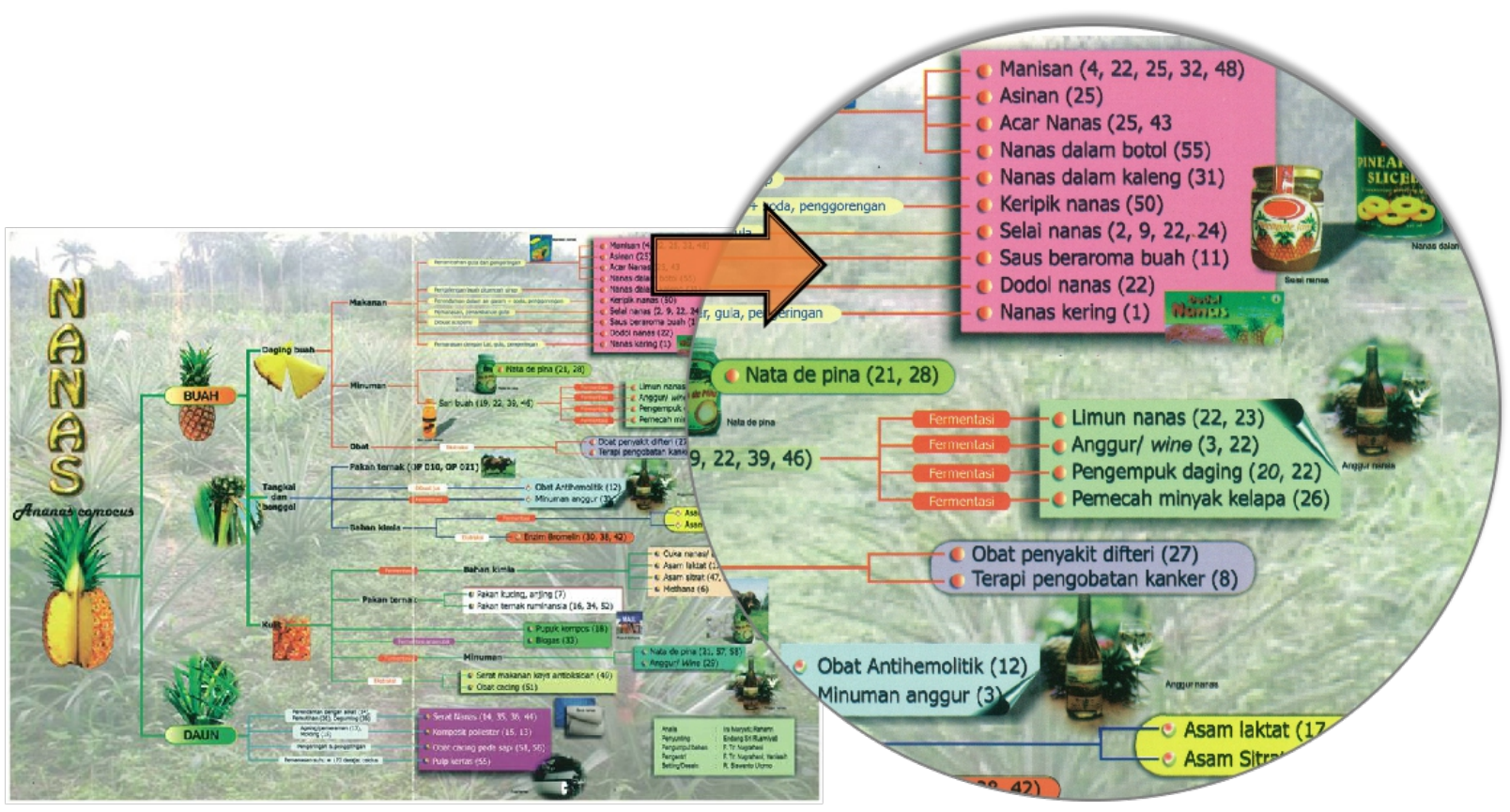

Gambar 1. Pohon Industri Nanas PDDI dibuat pada tahun 2008

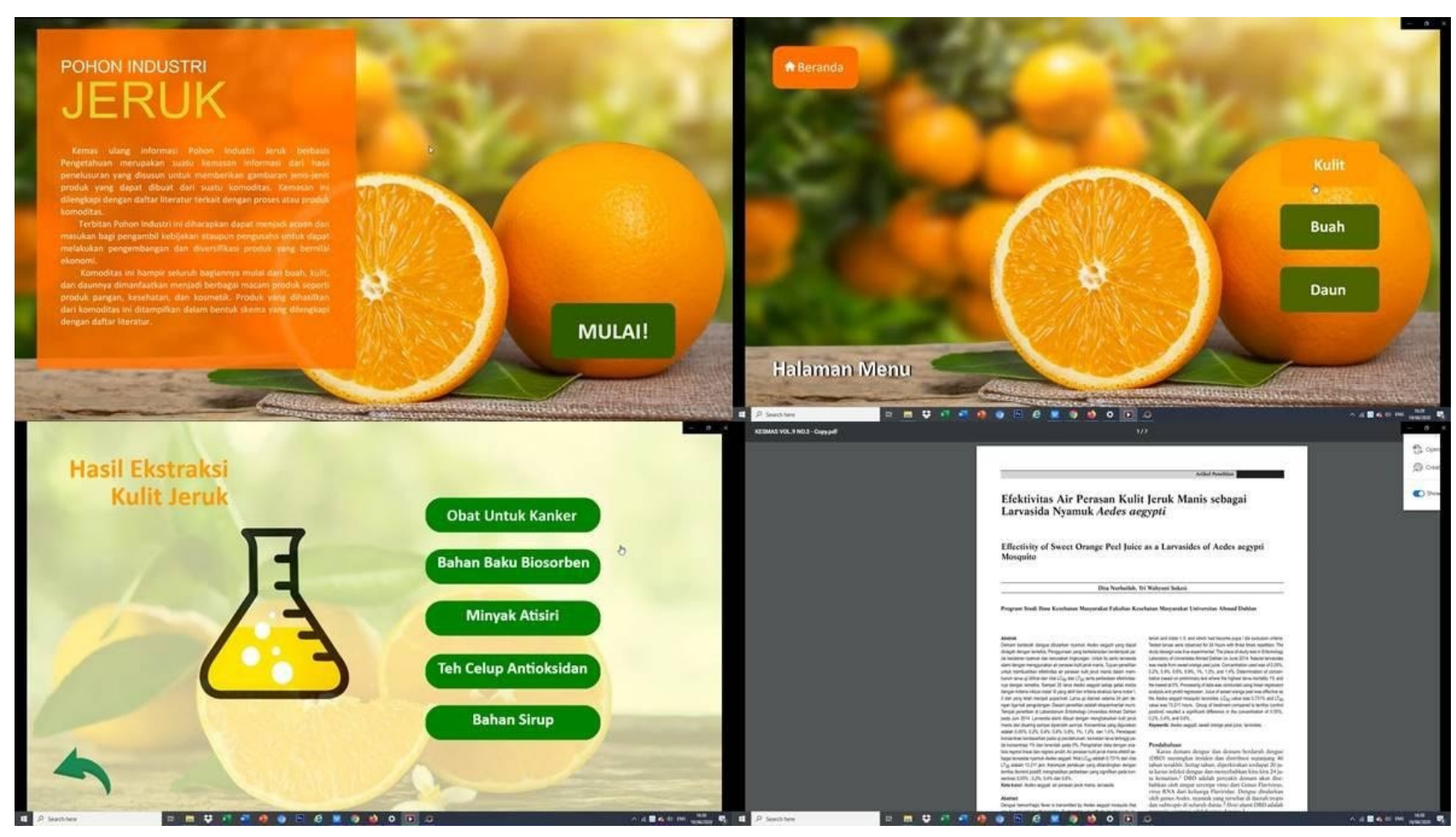

Gambar 2. Pohon Industri Interaktif Jeruk PDDI 2019 


\section{DAFTAR GAMBAR}

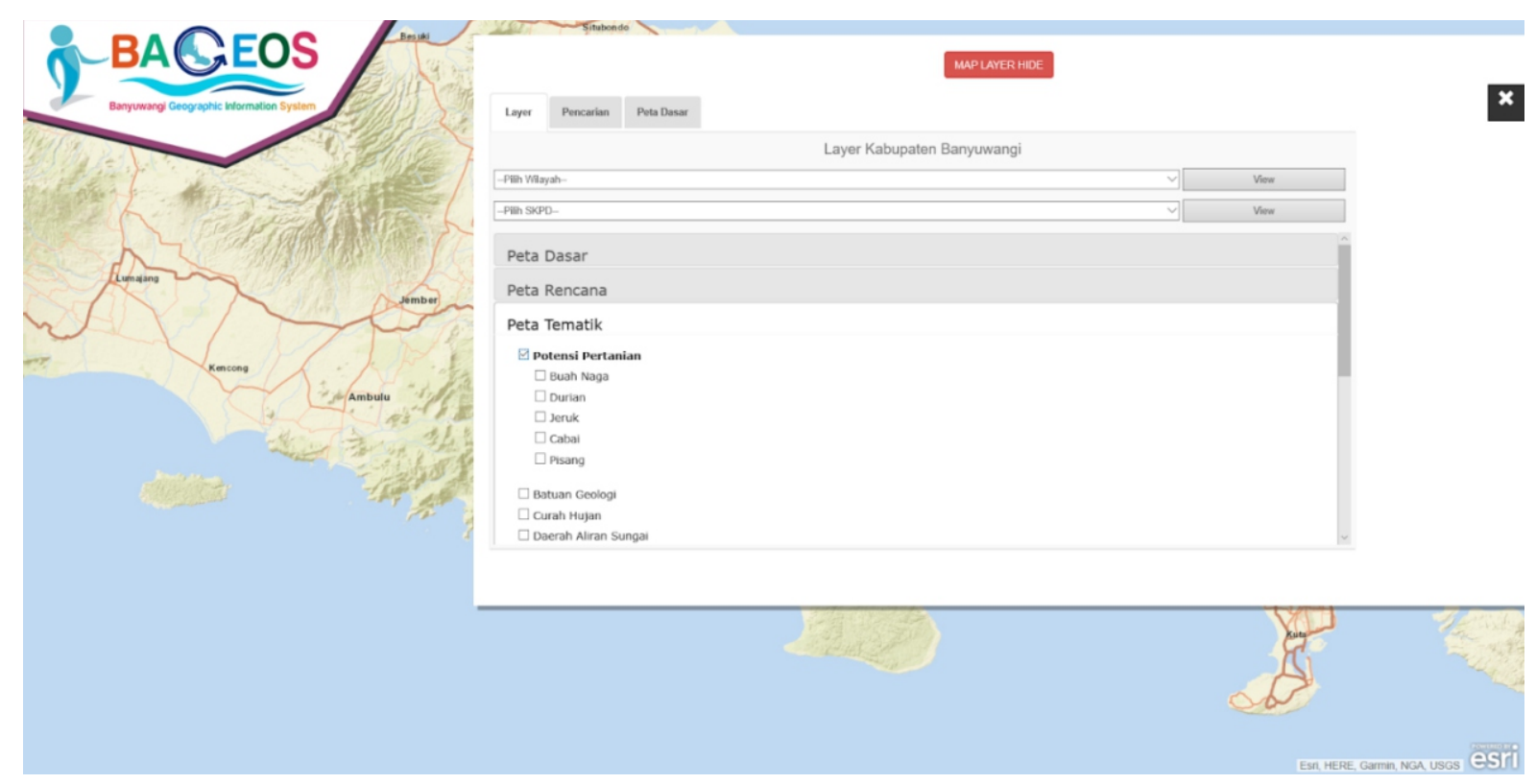

Gambar 3. Tampilan WebGIS BAGEOS milik Pemkab. Banyuwangi, 2019

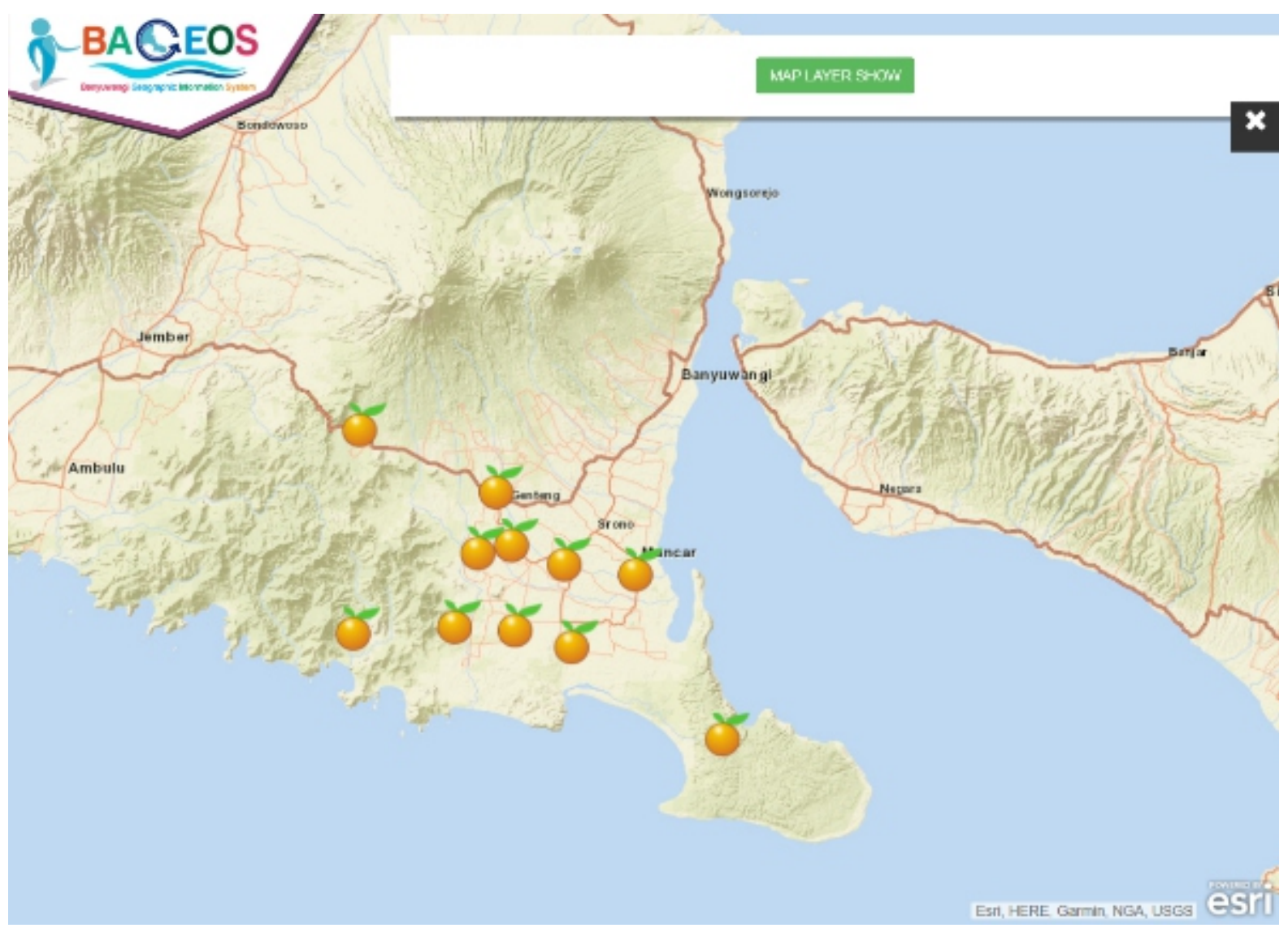

Gambar 4. Tampilan WebGIS BAGEOS dengan menampilkan ikon buah jeruk, 2019 


\section{DAFTAR TABEL}

Tabel 1. Manfaat dari pohon industri menurut responden (Jakarta)

\begin{tabular}{ccc}
\hline $\begin{array}{c}\text { Yang akan mendapatkan manfaat dari pohon } \\
\text { industri }\end{array}$ & $\begin{array}{c}\text { Frekuensi } \\
(\mathbf{n = 2 4 )}\end{array}$ & \% \\
\hline Masyarakat umum & 20 & $83,3 \%$ \\
Peneliti & 19 & $79,2 \%$ \\
Mahasiswa & 17 & $70,8 \%$ \\
Pelajar & 15 & $62,5 \%$ \\
Entrepreneur/pebisnis/wirausaha & 15 & $62,5 \%$ \\
Atasan di instansi & 1 & $4,2 \%$ \\
PNS & 1 & $4,2 \%$ \\
Penyuluh & 1 & $4,2 \%$ \\
\hline
\end{tabular}

Sumber: Data primer diolah 2019

Tabel 2. Manfaat dari pohon industri menurut responden (Banyuwangi)

\begin{tabular}{ccc}
\hline Yang akan mendapatkan manfaat dari pohon & Frekuensi \\
industri & $\mathbf{( n = 2 7 )}$ & $\%$ \\
\hline Peneliti & 23 & $85,2 \%$ \\
Mahasiswa & 21 & $77,8 \%$ \\
Entrepreneur/pebisnis/wirausaha & 21 & $77,8 \%$ \\
Masyarakat umum & 21 & $77,8 \%$ \\
Dosen & 19 & $70,4 \%$ \\
Pelajar & 15 & $55,6 \%$ \\
Guru & 12 & $44,4 \%$ \\
PNS & 12 & $44,4 \%$ \\
UKM & 1 & $3,7 \%$ \\
\hline
\end{tabular}

Sumber: Data primer diolah 2019 